\title{
FINANCIAL AND OPERATING RISK ANALYSIS OF TWO ROMANIAN-HUNGARIAN
} BORDER COUNTIES

\author{
Tibor Tarnóczi, Edit Veres, Edina Kulcsár \\ Department of Economics, Faculty of Economics and Social Sciences, Partium Christian \\ University, Oradea, Romania \\ tarnoczi.tibor@partium.ro \\ veres.edit@partium.ro \\ kulcsar.edina@partium.ro
}

\begin{abstract}
The study analyzes the risk of companies selected from two Romanian-Hungarian border counties (Bihor and Hajdú-Bihar counties) by the degree of operational and financial leverage ratios. A total of 1,674 companies from the two counties were included in the analysis, in approximately half and half proportions. In the study, operating, financial and combined leverage ratios are used for risk analysis. Because of the large variance of the ratios, outliers were filtered out. The filtering was based on the degree of the combined leverage ratio, which resulted in 107 companies excluded. In the analysis of sectors, there are significant differences in DOL ratio values between counties. For the DFL indicator, the values are much more balanced. There are also larger differences for DCL, which are likely to be caused by DOL values. The analysis showed no statistically significant difference in leverage ratios between the total county data or the sector-disaggregated county data. The analysis also suggested that some accounting reports may contain manipulations but that further investigations are needed to substantiate them adequately.
\end{abstract}

Keywords: corporate risk; degree of operating leverage; degree of financial leverage; comparative financial analysis

JEL Classification: G32, M10

\section{Introduction}

Risk or uncertainty occurs when an event has over one output, and we cannot know the outcome of the output with certainty, it can only make probable. With the economic systems, we do not have accurate information or knowledge about the extent and direction of the change concerning a future event that causes the risk. Different methods can usually estimate the extent of the change. Determining the direction of change implies more significant uncertainty and risk.

Nowadays, suitable risk identification and management are playing an essential role in corporate governance. There are simpler and more complex methods to determine risk, ranging from financial ratios to simpler and more complex statistical methods to various simulation models. The company's fundamental financial goal is to create value, for which the company must generate income. In order for a company to increase its value, it must exceed the cost of capital compared to income. Achieving the expected income level can be influenced by many factors, one of the most important of which is fixed costs. The development of fixed costs is often referred to as leverage because fixed costs act as a pivot point for a company's income. This means that leverage can affect corporate income in both positive and negative directions.

Leverage, therefore, means the use of fixed costs in a company's cost structure. Fixed costs that are operating costs (such as depreciation or rent) create operating leverage. Financial fixed costs (such as interest expense) create financial leverage. Thus, in a corporate context, leverage refers to the effect of fixed costs on income, which can have an increasing or a 
decreasing effect, and these effects can be very significant in both directions due to leverage.

In this study, we examine operational and financial leverage by using the financial data of companies from two neighbouring Romanian-Hungarian border counties, Bihor and HajdúBihar counties. In the course of the research, analyzes were performed to answer the following hypotheses:

1. There is no statistically significant difference between the two counties examined in terms of operational and financial risks.

2. In terms of operational and financial risks, the selected sectors differ statistically significantly, but there are no differences between the counties in this respect either.

3. Financial statements give a reliable and fair view of businesses and, as a result, provide a sound basis for identifying and analyzing corporate risks.

\section{Literature review}

The concept of degree of operating leverage (DOL) and degree of financial leverage (DFL) has long been found in the international literature. In his 1995 study, Lord examined the relationship between DOL and the break-even point. He found that the change in both fixed cost and the variable cost was positively related to the change in DOL. It also raised three alternative calculation possibilities for calculating the DOL, which is still known today, but no data are available for an external analyst to calculate two of them. Darrat and Mukherjee wrote in 1995 that the value of combined leverage (DCL) is not only a function of operational (DOL) and financial leverage (DFL), but other risk factors may play a role in the evolution of DCL. It also assumes that there should be a negative correlation between DOL and DFL.

Chen et al. (2019) was established that DOL has a first-order impact on corporate policy and performance. DOL can be positively related to profitability. If sales are increasing and the fixed costs grow less than sales, higher operating leverage causes higher profitability.

Sarkar (2020) examined the relationship between DOL and DFL. He noted that the two indicators do not always behave as substitutes for each other, as was previously stated in the literature. According to him, the relationship between the two variables is very complex, so the relationship can only be explored appropriately if relevant conditions are provided. This would be necessary because it can be seen from the previous literature that researchers found a negative and positive correlation between DOL and DFL at one time. $\mathrm{He}$ also suggests that indicators could be used to determine the risk of bankruptcy.

Tao et al. (2020) analyzed the relationship between DOL, profitability, and DFL in their research. DOL and profitability were found to be positively related. They found that DOL increases profitability and has a reducing effect on the company's optimal capital structure. Therefore, in their view, DOL is negatively related to profitability and DFL. DOL is thought to be the main reason for the reverse relationship between profitability and DFL when a company's revenue declines. It was also noted that the company's risk of bankruptcy might be related to the higher DOL. Because of the above, DOL is considered a critical indicator. In his article, Sarkar (2018) presents the derivation of an optimal DOL value for a company. It also notes that the choice of DOL is of great importance because it can also affect a company's level of risk and operational and financial performance. To determine the optimal value of DOL, use a real options model that can consider managerial decision flexibility. He also points out that several factors can affect DOL.

Ekhal (2019) examined the relationship between financial leverage and business risk. The study used an alternative replacement of business risk, separated from the effects of financial leverage. This replacement was the cost of capital of a firm that had only equity. This construction shows a positive relationship between business risk and financial leverage. Stelk et al. (2018) found that the traditional accounting measure of DFL gives statistically different estimates compared to estimates based on the elasticity measure of DFL. 
Cao (2015) examined that adjusted cost, DOL and DFL are affect value premium in his study. The author found that DFL, supported by adjusted cost, significantly impacts value premium, while DOL does not affect it significantly.

Zia ul haq et al. (2020) provide empirical evidence by investigating the relationships of DFL and DOL with stock returns, the book value/market value ratio on non-financial sector firms of the Pakistan stock exchange. Their research finds the significant and direct effect of DOL on stock returns and the book value to market value ratio, respectively.

\section{Data and methodology}

\subsection{Database of the research}

The database was collected from the balance sheets and the income statements of examined companies which were downloaded from the EMIS database. EMIS contains several sectoral classifications. As the study analyzes companies from two countries, the NAICS code (North American Industry Classification System) was used to classify companies by sector. The distribution of the companies of the two counties according to the NAICS code is shown in Table 1. The data selection criteria included that the company's total revenue should reach EUR 100 thousand and the total assets of the company should reach EUR 50 thousand in each of the years examined (2014-2018). Companies also had to have financial statements every year. 839 companies met the specified conditions in Bihor county, while 835 companies in Hajdú-Bihar county. Table 1 shows that nearly the same number of companies from the two neighbouring counties were included in the study. Sectors in which the number of companies reached 10 in both counties were compared per county. In Table 1, the sectors that meet the previous condition are marked in grey colour. It can be seen in the table that nine sectors met the condition, which is $94.04 \%$ of companies in the database in Bihor County and $90.54 \%$ in Hajdú-Bihar County.

Table 1: The distribution of the companies of the two counties according to the NAICS code

\begin{tabular}{|c|l|r|r|}
\hline $\begin{array}{c}\text { NAIC } \\
\text { code }\end{array}$ & \multicolumn{1}{|c}{$\begin{array}{c}\text { Bihor } \\
\text { County }\end{array}$} & $\begin{array}{c}\text { Hajdú- } \\
\text { Bihar } \\
\text { County }\end{array}$ \\
\hline 11 & Agriculture, Forestry, Fishing and Hunting & 61 & 69 \\
\hline 22 & Utilities & 6 & 12 \\
\hline 23 & Construction & 61 & 99 \\
\hline 31 & Manufacturing & 202 & 149 \\
\hline 42 & Wholesale Trade & 198 & 182 \\
\hline 44 & Retail Trade & 94 & 146 \\
\hline 48 & Transportation and Warehousing & 124 & 47 \\
\hline 51 & Information & 9 & 11 \\
\hline 53 & Real Estate Rental and Leasing & 9 & 30 \\
\hline 54 & Professional, Scientific, and Technical & 12 & 19 \\
\hline 56 & Services & 22 & 28 \\
\hline 62 & Maninagement and Remediation Services & 7 & 9 \\
\hline 71 & Arts, Entertainment, and Recreation & 10 & 5 \\
\hline 72 & Accommodation and Food Services & 15 & 17 \\
\hline
\end{tabular}




\begin{tabular}{|c|l|r|r|r|}
\hline 81 & $\begin{array}{l}\text { Other Services (except Public } \\
\text { Administration) }\end{array}$ & 9 & 12 \\
\hline County total & 839 & 835 \\
\hline
\end{tabular}

Source: calculated by $\mathrm{R}$ statistics system, edited by authors

\subsection{Methods using for research}

\subsubsection{Calculation of degrees of leverages and presentation of their relationships}

The degree of operational leverage (DOL) and financial leverage (DFL) was used to measure corporate risk. Calculations were performed using formulas (1), (2) and (3). Using formulas (1) and (2) was necessary because no data (e.g., fixed and variable costs) were available to apply direct formulas. The calculation and interpretation of the degree of operational and financial leverage are dealt with in almost all corporate finance and financial management books, such as Brigham and Davis (2019), Wahlen et al. (2011), Moyer et al. (2012), Parrino et al. (2012), Keown et al. (2014).

$$
\begin{aligned}
\mathrm{DOL} & =\frac{\% \Delta \text { in EBIT }}{\% \Delta \text { in Sales }} \\
\mathrm{DFL} & =\frac{\% \Delta \text { in Net profit }}{\% \Delta \text { in EBIT }} \\
\mathrm{DCL} & =\mathrm{DOL}{ }^{*} \mathrm{DFL}=\frac{\% \Delta \text { in Net profit }}{\% \Delta \text { in Sales }}
\end{aligned}
$$

\subsubsection{Methods for comparison}

Pair-wise t-test, analysis of variance (ANOVA), and multivariate analysis of variance (MANOVA) were used to compare counties and companies. The pair-wise t-test was used when two data sets were compared, such as comparing counties per ratios or comparing sectors per ratios. Analysis of variance was used when comparing sectors by a ratio in a given county. Multivariate analysis of variance was needed to compare counties or sectors by considering multiple ratios simultaneously.

\section{Results of the research}

\subsection{General statistical analysis of the database}

A pair-wise t-test was performed by county and by indicators (DOL, DFL, DCL) to determine that there is a statistically significant difference between the data of four years, which showed that the years did not differ. As no statistically significant difference can be detected between the yearly data of the ratios examined, the years' average is used in the analysis.

The company data is usually characterized by outliers that can worsen the analysis. Because the research compares the data of the counties and their selected sectors and draws conclusions concerning them, the analysis must be performed on relatively homogeneous data. First, the DCL is examined and compared because it is the product of the DOL and the DFL, so it can better indicate outliers. Table 2 presents the main statistical characteristics of the DCL indicator by county. The minimum and maximum values in the table clearly show that there are outliers in both the negative and positive directions that need to be considered. A frequency distribution table for the DCL ratio will also be prepared to show the number of outliers in both directions. 
Table 2: Main statistical characteristics of the DCL ratio by the county before filtering outliers

\begin{tabular}{|l|r|r|}
\hline \multicolumn{1}{|c|}{ Statistical indicators } & \multicolumn{1}{|c|}{ Bihor County } & Hajdú-Bihar County \\
\hline Number of companies & 839 & 835 \\
\hline Minimum & $-5,708.64$ & $-7,284.52$ \\
\hline Quartile 1 & -1.74 & -1.19 \\
\hline Median & 1.83 & 2.36 \\
\hline Quartile 3 & 7.15 & 8.22 \\
\hline Maximum & $1,403.06$ & $2,271.76$ \\
\hline IQR & 8.89 & 9.41 \\
\hline Mean & -0.58 & 5.58 \\
\hline Standard deviation & 256.03 & 290.87 \\
\hline CV\% & $-44,459.56 \%$ & $-18.00 \%$ \\
\hline Skewness & -14.83 & 476.41 \\
\hline Kurtosis & 322.82 & \\
\hline
\end{tabular}

Source: calculated by $\mathrm{R}$ statistics system, edited by authors

Further evaluating Table 2 shows that the average DCL value of the companies of Bihor county is negative, while that of Hajdú-Bihar counties is positive. The standard deviation of the DCL ratio values of the companies in the two counties does not differ significantly, but since the average of Bihor county is much smaller than Hajdú-Bihar county, the value of the coefficient of variation is very high in Bihor county. Based on the skewness and kurtosis values, it can also be seen that the county databases differ from the normal distribution before filtering.

Table 3 shows the distribution of DCL ratio values. The distribution of indicator values in the two counties is very similar that can be seen from the table. It can be read out from the table that if values less than -100 and over 100 were excluded from the analysis, it would reduce the number of companies examined by $5.72 \%$ (48 firms) in Bihor County and by $7.07 \%$ in Hajdú-Bihar County (59 firms). So for the entire database, 107 companies were omitted, which is $6.39 \%$ of all companies.

Table 3: Distribution of DCL ratio values by county

\begin{tabular}{|r|r|r|r|r|r|}
\hline \multicolumn{2}{|c|}{ Intervals } & \multicolumn{2}{|c|}{ Bihor County } & \multicolumn{2}{c|}{ Hajdú-Bihar County } \\
\hline lower limit & $\begin{array}{c}\text { upper } \\
\text { limit }\end{array}$ & frequency & $\%$ & frequency & $\%$ \\
\hline-1000 & & 2 & $0.24 \%$ & 2 & $0.24 \%$ \\
\hline-1000 & -500 & 2 & $0.24 \%$ & 2 & $0.24 \%$ \\
\hline-500 & -300 & 5 & $0.60 \%$ & 4 & $0.48 \%$ \\
\hline-300 & -100 & 13 & $1.55 \%$ & 14 & $1.68 \%$ \\
\hline-100 & -50 & 20 & $2.38 \%$ & 12 & $1.44 \%$ \\
\hline-50 & 0 & 232 & $27.65 \%$ & 226 & $27.07 \%$ \\
\hline 0 & 50 & 512 & $61.03 \%$ & 513 & $61.44 \%$ \\
\hline 50 & 100 & 27 & $3.22 \%$ & 25 & $2.99 \%$ \\
\hline 100 & 300 & 14 & $1.67 \%$ & 23 & $2.75 \%$ \\
\hline 300 & 500 & 4 & $0.48 \%$ & 5 & $0.60 \%$ \\
\hline 500 & 1000 & 4 & $0.48 \%$ & 5 & $0.60 \%$ \\
\hline 1000 & & 4 & $0.48 \%$ & 4 & $0.48 \%$ \\
\hline & Total & 839 & $100.00 \%$ & 835 & $100.00 \%$ \\
\hline
\end{tabular}

Source: calculated by $\mathrm{R}$ statistics system, edited by authors 
The main statistical characteristics of the database after filtering out the outliers are given in Table 4. The values in Table 4 have changed significantly from the values in Table 2 . There was a particularly significant change in the values of standard deviations and coefficients of variation. The analyzes were performed based on the filtered database.

Table 4: Main statistical characteristics of the DCL ratio by the county after filtering outliers

\begin{tabular}{|l|r|r|}
\hline Statistical indicators & \multicolumn{1}{|c|}{ Bihor County } & Hajdú-Bihar County \\
\hline Number of companies & 791 & 776 \\
\hline Minimum & -97.99 & -92.88 \\
\hline 1. Quartile & -1.47 & -0.98 \\
\hline Median & 1.80 & 2.23 \\
\hline 3. Quartile & 6.60 & 6.91 \\
\hline Maximum & 98.88 & 95.22 \\
\hline IQR & 8.07 & 7.89 \\
\hline Mean & 2.84 & 3.70 \\
\hline Standard deviation & 21.59 & 20.24 \\
\hline CV\% & $759.47 \%$ & $547.32 \%$ \\
\hline Skewness & 0.14 & 0.08 \\
\hline Kurtosis & 6.82 & 6.89 \\
\hline
\end{tabular}

Source: calculated by $\mathrm{R}$ statistics system, edited by authors

\subsection{Comparison of two counties}

The comparison of the DOL, DFL and DCL ratios for the two counties was presented in Table 5. Although the counties' average values differ, no statistically significant difference can be detected between them. The last row of the table contains the $p$-value of MANOVA, where two counties were compared using the three indicators together. The results of the ttest and the MANOVA verified Hypothesis 1 that is there is no statistically significant difference between the two counties examined in terms of operational and financial risks.

Table 5: Comparison of companies' leverage ratios by county

\begin{tabular}{|l|r|r|r|}
\hline \multicolumn{1}{|c|}{ Ratios } & $\begin{array}{c}\text { Average values of } \\
\text { Bihor County }\end{array}$ & $\begin{array}{c}\text { Average values of } \\
\text { Hajdú-Bihar County }\end{array}$ & \multicolumn{1}{c|}{ p-value } \\
\hline DOL & $-3,781$ & 4,984 & $17,89 \%$ \\
\hline DFL & 0,989 & 1,280 & $70,30 \%$ \\
\hline DCL & 2,843 & 3,697 & $41,90 \%$ \\
\hline DOL, DFL, DCL & \multicolumn{3}{|r|}{} \\
\hline
\end{tabular}

Source: calculated by $\mathrm{R}$ statistics system, edited by authors

\subsection{Comparison of the sectors}

A comparison of DOL, DFL, and DCL indicators by sector and county also showed no statistically significant difference between counties even when they are broken down into sectors (Table 6-8).

Table 6: Comparison of companies' DOL ratios by sector and by county

\begin{tabular}{|c|l|r|r|r|}
\hline $\begin{array}{c}\text { Sector } \\
\text { code }\end{array}$ & \multicolumn{1}{|c|}{ Sector name } & $\begin{array}{c}\text { Average } \\
\text { values of } \\
\text { Bihor } \\
\text { County }\end{array}$ & $\begin{array}{c}\text { Average } \\
\text { values of } \\
\text { Hajdú-Bihar } \\
\text { County }\end{array}$ & p-value \\
\hline 11 & $\begin{array}{l}\text { Agriculture, Forestry, Fishing and } \\
\text { Hunting }\end{array}$ & 5,024 & 6,538 & $90,06 \%$ \\
\hline 23 & Construction & 3,445 & 5,261 & $68,88 \%$ \\
\hline
\end{tabular}




\begin{tabular}{|c|l|r|r|r|}
\hline 31 & Manufacturing & 0,820 & 1,344 & $97,37 \%$ \\
\hline 42 & Wholesale Trade & 0,655 & 15,152 & $18,49 \%$ \\
\hline 44 & Retail Trade & 329,409 & 3,443 & $39,20 \%$ \\
\hline 48 & Transportation and Warehousing & $-69,793$ & $-0,660$ & $33,14 \%$ \\
\hline 54 & $\begin{array}{l}\text { Professional, Scientific, and } \\
\text { Technical Services }\end{array}$ & 5,981 & 3,694 & $74,50 \%$ \\
\hline 56 & $\begin{array}{l}\text { Administrative and Support and } \\
\text { Waste Management and } \\
\text { Remediation Services }\end{array}$ & $-2,102$ & 9,387 & $46,53 \%$ \\
\hline 72 & $\begin{array}{l}\text { Accommodation and Food } \\
\text { Services }\end{array}$ & $-2,414$ & 1,656 & $34,49 \%$ \\
\hline
\end{tabular}

Source: calculated by $\mathrm{R}$ statistics system, edited by authors

Table 6 shows the results of the sector-by-sector comparison of counties for DOL. The table shows that the most extreme average DOL values are found in sectors 44 and 48 in Bihor County. The average values of Hajdú-Bihar county are more balanced.

The DFL mean values in Table 7 show relatively balanced values in both counties. From a comparison of Tables 6 and 7, it can be concluded that firms pay more attention to financial risks than to operating risks. At the same time, it would also be important to pay more attention to operating leverage, as it can also have a significant impact on a company's risk level and financial performance, as found in Sarkar's (2018) study.

Table 7: Comparison of companies' DFL ratios by sector and by county

\begin{tabular}{|c|l|r|r|r|}
\hline $\begin{array}{c}\text { Sector } \\
\text { code }\end{array}$ & \multicolumn{1}{|c|}{ Sector name } & $\begin{array}{c}\text { Average } \\
\text { values of } \\
\text { Bihor } \\
\text { County }\end{array}$ & $\begin{array}{c}\text { Average } \\
\text { values of } \\
\text { Hajdú-Bihar } \\
\text { County }\end{array}$ & p-value \\
\hline 11 & $\begin{array}{l}\text { Agriculture, Forestry, Fishing and } \\
\text { Hunting }\end{array}$ & 1,304 & 1,509 & $68,15 \%$ \\
\hline 23 & Construction & 1,583 & 0,678 & $17,49 \%$ \\
\hline 31 & Manufacturing & 3,116 & 2,297 & $62,21 \%$ \\
\hline 42 & Wholesale Trade & 1,076 & 1,287 & $74,90 \%$ \\
\hline 44 & Retail Trade & 1,317 & 0,960 & $58,36 \%$ \\
\hline 48 & Transportation and Warehousing & $-0,519$ & 1,160 & $70,61 \%$ \\
\hline 54 & $\begin{array}{l}\text { Professional, Scientific, and } \\
\text { Technical Services }\end{array}$ & 1,459 & 0,953 & $25,75 \%$ \\
\hline 56 & $\begin{array}{l}\text { Administrative and Support and } \\
\text { Waste Management and } \\
\text { Remediation Services }\end{array}$ & 1,852 & 1,337 & $36,93 \%$ \\
\hline 72 & $\begin{array}{l}\text { Accommodation and Food } \\
\text { Services }\end{array}$ & 0,889 & 3,269 & $30,56 \%$ \\
\hline
\end{tabular}

Source: calculated by $\mathrm{R}$ statistics system, edited by authors

The DCL averages in Table 8 also differ significantly across the sectors studied for both counties. The difference is most likely due to differences in DOL. The sectors were also compared within the counties, but in this case, no statistically significant difference could be detected with the analysis of variance. In Bihor county, the significance level $p$ was $69.6 \%$, and in Hajdú-Bihar county, 83.7\%.

The first half of Hypothesis 2 should be rejected based on the results because the examined sectors do not differ statistically significantly. However, the second half of Hypothesis 2 is 
acceptable because no significant difference can be detected between the counties by sectors.

Table 8: Comparison of companies' DCL ratios by sector and by county

\begin{tabular}{|c|l|r|r|r|}
\hline $\begin{array}{c}\text { Sector } \\
\text { code }\end{array}$ & \multicolumn{1}{|c|}{ Sector name } & $\begin{array}{c}\text { Average } \\
\text { values of } \\
\text { Bihor } \\
\text { County }\end{array}$ & $\begin{array}{c}\text { Average } \\
\text { values of } \\
\text { Hajdú-Bihar } \\
\text { County }\end{array}$ & p-value \\
\hline 11 & $\begin{array}{l}\text { Agriculture, Forestry, Fishing and } \\
\text { Hunting }\end{array}$ & 11,275 & $-104,933$ & $27,78 \%$ \\
\hline 23 & Construction & $-2,719$ & 5,872 & $18,26 \%$ \\
\hline 31 & Manufacturing & 16,940 & 11,119 & $70,71 \%$ \\
\hline 42 & Wholesale Trade & $-1,677$ & 18,006 & $17,09 \%$ \\
\hline 44 & Retail Trade & $-50,914$ & 22,766 & $25,16 \%$ \\
\hline 48 & Transportation and Warehousing & 11,688 & $-3,548$ & $62,99 \%$ \\
\hline 54 & $\begin{array}{l}\text { Professional, Scientific, and } \\
\text { Technical Services }\end{array}$ & 9,721 & 5,461 & $62,02 \%$ \\
\hline 56 & $\begin{array}{l}\text { Administrative and Support and } \\
\text { Waste Management and } \\
\text { Remediation Services }\end{array}$ & $-1,292$ & 53,988 & $18,53 \%$ \\
\hline 72 & $\begin{array}{l}\text { Accommodation and Food } \\
\text { Services }\end{array}$ & 11,933 & 7,225 & $72,24 \%$ \\
\hline
\end{tabular}

Source: calculated by R statistics system, edited by authors

Correlation coefficients between leverage ratios and profitability ratios were also calculated during the analysis, but no weak correlation was detected. Of the correlation values got, the highest value in absolute value was 0.0951 . Thus, there was no significant correlation between leverage ratios and profitability ratios for the companies examined.

\section{Conclusions}

Based on the leverage-based risk analysis of the companies of Bihor and Hajdú-Bihar counties, it can be stated that no statistically significant difference can be detected between the companies of the two counties according to the examined aspects. It can also be stated that companies in the two counties are likely to pay more attention to financial risks than to their operational risk. The latter may also mean that companies have more control over their indebtedness than their hedging revenues. It would also be important to note that the risk posed by operational leverage can lead to corporate bankruptcies in the same way as high financial risk.

Based on the analysis, considering the data in Table 2, the company accounts do not always reflect a reliable and fair view of the company's financial position. There may be a significant number of companies that may have been the financial statements manipulated. These manipulations can lead to inconsistencies between the ratios calculated from these data. Further investigations would be needed to substantiate this finding. However, in the analysis, they were expressed and calculated at a fixed cost using the basic formula of DOL, which highlighted significant inconsistencies. There were also negative values for the calculated values and some calculated values greater than the total costs calculated from the data.

Hypothesis 3 may be rejected because of the above, but it should be emphasized that separate studies would be needed to substantiate this fully.

It would be expedient to continue the study with other methods and other classifications to form a more substantiated picture of the risk situation of the examined counties and sectors. 


\section{Acknowledgements}

The Pallas Athene Domus Educationis Foundation supported the research, "The comparative financial-economic analysis of Romanian-Hungarian border enterprises" was performed within the framework of a project.

\section{References}

1. Brigham, E.F. \& Daves, P.R. (2019) Intermediate Financial Management, 13th Edition, Cengage Learning, Inc., ISBN: 978-1-337-39508-3

2. Cao, V.N. (2015) What Explains the Value Premium? The Case of Adjustment Costs, Operating Leverage and Financial Leverage, Journal of Banking \& Finance, Vol. 59, October 2015, pp. 350-366. 3. Chen, Z., Harford, J., \& Kamara, A. (2019) Operating Leverage, Profitability, and Capital Structure, Journal of Financial and Quantitative Analysis, Vol. 54, No. 1, pp. 369-392.

4. Darrat, A.F., \& Mukherjee, T.K. (1995) Inter-industry differences and the impact of operating and financial leverages on equity risk, Review of Financial Economics, Vol. 4, No. 2, pp. 141-155

5. Elkhal, K. (2019) Business uncertainty and financial leverage: should the firm double up on risk? Managerial Finance, Vol. 45, No. 4, pp. 536-544.

6. Keown, A.J., Martin, J.D., \& Petty, J.W. (2014) Foundations of finance: the logic and practice of financial management, 8th ed., Pearson, ISBN 978-0-13-299487-3

7. Lord, R.A. (1995) Interpreting and Measuring Operating Leverage, Issues in Accounting Education, Vol. 10, No. 2, pp. 317-329.

8. Moyer, R.C., McGuigan, J.R., Rao, R., \& Kretlow, W.J. (2012) Contemporary Financial Management, Twelfth Edition, South-Western, Cengage Learning, ISBN: 978-0-538-47916-5

9. Parrino, R., Kidwell, D.S., \& Bates, T.W. (2012) Fundamentals of corporate finance, John Wiley \& Sons, Inc., ISBN: 978-0-470-87644-2

10. Sarkar, S. (2018) Optimal DOL (degree of operating leverage) with investment and production flexibility, International Journal of Production Economics, 202, 172-181.

11. Sarkar, S. (2020) The relationship between operating leverage and financial leverage, Accounting \& Finance, 60 (2020), pp. 805-826.

12. Stelk, S., Park, S-H., Medcalfe, S., \& Dugan, M.T. (2018) An additional analysis of estimation techniques for the degree of financial leverage, Review of Financial Economics, Vol. 36, No. 3, pp. 197-283.

13. Tao, Q., Zahid, Z., \& Mughal, A. (2020) Does operating leverage increase firm's profitability and bankruptcy risk? Evidence from China's entry into WTO, International Journal of Finance\&Economics, 2020, pp. 1-17.

14. Wahlen, J.M., Baginski, S.P., \& Bradshaw, M.T. (2011) Financial Reporting, Financial Statement Analysis, and Valuation: A Strategic Perspective, Seventh Edition, South-Western, Cengage Learning, ISBN: 978-0-324-78941-6

15. Zia ul haq, H.M., Shafiq, M.S., Kashif, M., \& Saba Ameer, S. (2020) Determining Force behind Value Premium: The Case of Financial Leverage and Operating Leverage, Journal of Risk and Financial Management, Vol. 13, No. 9, pp. 196-210. 